\title{
The Satisfaction of Corporate Customer at Agribank in Ho Chi Minh City
}

\author{
Nguyen Quoc Huy ${ }^{1} \&$ Pham Hung Cuong ${ }^{2}$ \\ ${ }^{1}$ Lac Hong University, Vietnam. \\ ${ }^{2}$ Foreign Trade University, Ho Chi Minh City Campus, Vietnam. \\ Correspondence: Pham Hung Cuong, Foreign Trade University, Ho Chi Minh City Campus, Vietnam.
}

Received: February 15, 2015

Accepted: February 26, 2015

Available online: March 12, 2015

doi:10.11114/aef.v2i2.715

URL: http://dx.doi.org/10.11114/aef.v2i2.715

\begin{abstract}
In this paper, the authors use analytical method of explore factor analysis to determining factors that are components of the corporate customer satisfaction in Ho Chi Minh City (HCMC). This paper conducted during the period from March 2012 to December 2014.

The exploratory factor analysis result showed that there were five factors, which included of factors following the service behavior, the tangible and the competitive price, the reliance, the convenience and the Agribank Image that are components of the corporate customer satisfaction with significance level $5 \%$. In addition, the research result processed from SPSS 20.0 software. The research result showed that there were nearly 550 corporates of Agribank in HCMC interviewed but 503 corporates (47 samples mistaken) to be processed and answered about 30 questions. The researcher had analyzed KMO test. The corporate responses measured through an adapted questionnaire on a 5-point Likert scale. Hard copy and interview the corporate by questionnaire distributed among corporate of Agribank in HCMC. At the same time, the result was also a scientific evidence and important for researchers, and policy makers who apply them for improving the corporate customer satisfaction in HCMC.
\end{abstract}

The researchers had obtained the main objectives of this study were to:

1. The first objective, the authors had to conduct a survey to find factors that are components of the corporate customer satisfaction of Agribank in HCMC.

2. The second objective, the authors had to identify some factors that are components in the corporate customer satisfaction in HCMC.

Keywords: customer satisfaction, HCMC, service quality and Agribank

\section{Introduction}

A customer satisfaction is an ambiguous and abstract concept. Actual manifestation of the state of satisfaction will vary from person to person, product to product and service to service. The state of satisfaction depends on a number of factors that consolidate as psychological, economic and physical factors. The quality of service is one of the major determinants of the customer satisfaction (Parasuraman, Zeithaml and Barry, 1985; 1998; Cronin and Taylor, 1994; Gronroos, 1984; Zeithaml, Parasuraman, and Malhotra, 2000; Schefter and Reichheld, 2000; Gommans, Krishnanand Scheffold, 2001; Yoo and Donthu, 2001 and Loiacono, Watson and Goodhue, 2002). Many researchers and experts mentioned that, service quality can be enhanced by using advanced information, communication technology (ICT) and others. Agribank is the leading bank in Viet Nam in receipt and implementation of foreign projects. In the context of economic volatility, Agribank has received 136 projects from the World Bank (WB), Asian Development Bank (ADB), French Development Agency (AFD), European Investment Bank (EIB), etc. with the total fund of over 5.1 billion of USD. Apart from this, Agribank has continuously got accessed to and attracted new projects: Financing Agreement with European Investment Bank (EIB) phase II; Rural Finance Project III funded by World Bank, Biogas Project funded by ADB; JBIC Project by Japan; Small rubber farming project funded by AFD.Therefore, the study of customer satisfaction for banks is an important job, to make regular, continuous to be able to respond promptly to changes in their needs so that we can can better serve our customers and make the customer is always satisfied when using the services and products of the bank. The title "THE CORPORATE CUSTOMER SATISFACTION IN AGRIBANK IN HO CHI 
MINH CITY" as a paper for researching in the corporate customer satisfaction.

\subsection{Literature Review}

Kotler and Clarke (1987) define satisfaction as a state felt by a person who has experienced performance or an outcome that fulfills his or her expectation. Satisfaction is a function of the relative level of expectation and perceived performance. With respect to a customer's expectation, it may go back as far as before the customers have bought a product or service, suggesting that it is important to first determine what the customers expect before buying a product or service (Palacio, Menses and Perez, 2002). In contrast, Carey, Cambiano and De Vore (2002), believe that satisfaction only covers issues of a customers' perception and experiences during the actual time spent in university.

Customer satisfaction. It is a term frequently used in marketing. It is a measure of how products and services supplied by a company meet or surpass customer expectation. Customer satisfaction is defined as the number of customers, or percentage of total customers, whose reported experience with a firm, its products, or its services (ratings) exceeds specified satisfaction goals. In a survey of nearly 200 senior marketing managers, 71 percent responded that they found a customer satisfaction metric very useful in managing and monitoring their businesses. It is seen as a key performance indicator within business and is often part of a Balanced Scorecard. In a competitive marketplace where businesses compete for customers, customer satisfaction is seen as a key differentiator and increasingly has become a key element of business strategy.

\section{Research Method}

This study used of quantitative research methods to survey the factors that affecting the corporate customer satisfaction of Agribank in HCMC. The results obtained from quantitative research processed by SPSS statistical software version 20.0 .

Quantitative research is the collection of numerical data and exhibiting the view of relationship between theory and research as deductive, a predilection for natural science approach, and as having an objectivist conception of social reality. Therefore, this specific form of research uses the quantitative data to analysis.

After preliminary investigations, formal research is done by using quantitative methods questionnaire survey of 550 the corporates of Agribank in HCMC and answered nearly 30 questions. The reason tested measurement models, model and test research hypotheses.Data collected were tested by the reliability index (excluding variables with correlation coefficients lower $<0.30$ and variable coefficient Cronbach's alpha $<0.60$ ), factor analysis explored (remove the variable low load factor $<0.50$ ). The hypothesis was tested through multiple regression analysis with linear Enter method.

\section{Research Result}

Agribank is the largest bank in Viet Nam in terms of capital, assets, workforce, operating network and customer base. As of December 2013, the leading role of Agribank has been confirmed by:

Total asset: VND 705,365 billion; Total fund resource: VND 626,390 billion

Equity: VND 29,605 billion; Total outstanding loans: VND 530,600 billion

Operating network: 2,300 branches and transaction offices nationwide and

Persons: 40,000 staffs.

Table 1. Descriptive Statistics for the corporate customer satisfaction of Agribank

\begin{tabular}{clcc}
\hline Code & Questionnaires & N & Mean \\
\hline TXKH1 & The Bank has diversified portfolio of services and rich & 503 & 3.0755 \\
TXKH2 & The Bank is proactive to provide new services to meet the growing needs of & 503 & 3.0517 \\
& customers & 503 & 3.0875 \\
TXKH3 & The Bank hotline is customer service 24/24 & 503 & 3.0795 \\
TXKH4 & The Bank staffs are regular contact with customers & 503 & 2.9662 \\
HADN1 & The Bank kept its reputation for customer & 503 & 2.7813 \\
HADN2 & The Bank is always at the forefront of innovation and social activities & 503 & 2.7157 \\
HADN3 & The Bank strategy is for sustainable development & 503 & 3.2803 \\
HADN4 & The Bank has a very effective marketing activities and impressive & 503 \\
SHH1 & The Bank of the document, photo books that introducing service very attractive & 3.1451 \\
SHH2 & The Bank of the transaction documents are clearly, no errors & 503 & 3.1670 \\
SHH3 & The Bank staffs are dressed and polite impression & 503 \\
TCTG1 & The Bank has interest rate that is competitive & 3.3360 \\
TCTG2 & The Transaction costs are reasonable & 503 & 3.3877 \\
\hline
\end{tabular}




\begin{tabular}{clcc} 
TCTG3 & The Bank has flexible pricing policy & 503 & 3.3221 \\
STT1 & The Bank has a wide network of agents & 503 & 3.5905 \\
STT2 & The Bank of Procedures and transactions are easily and quickly & 503 & 3.6382 \\
STT3 & The Banks have traded places convenient for customers & 503 & 3.5964 \\
STT4 & The Bank has facilities and modern machinery & 503 & 3.5626 \\
PCPV1 & The Bank staffs have good qualifications & 503 & 3.9523 \\
PCPV2 & The Bank staffs are to provide accurate and timely service & 503 & 3.9145 \\
PCPV3 & The Bank employees are to satisfactorily resolve customer complaints & 503 & 3.3658 \\
PCPV4 & The Bank staffs are always ready to serve customers & 503 & 3.6262 \\
PCPV5 & The Bank staffs are very courteous and considerate with customers & 503 & 3.3221 \\
\hline
\end{tabular}

Source: The researcher's collecting data and SPSS

Table 1 showed that there were 550 the corporates of Agribank in Ho Chi Minh City to be interviewed. There were minimum value was 1 , maximum value was 5 . Standard deviations were from 0.55429 to 1.328 ; mean is from 2.3777 to 3.9523. This data was very good for regression analysis.

\subsection{Exploratory Factor Analysis}

Test KMO and Bartlett shows two tests that indicate the suitability of your data for structure detection. The Kaiser-Meyer-Olkin Measure of Sampling Adequacy is a statistic that indicates the proportion of variance in your variables that might be caused by underlying factors. Reliability test: offer mainly Cronbach's alpha methods to show how well the measurements in a set of variables are well correlate with each other. According to Canava et al. (2001), he stated, "Cronbach's alpha is computed in terms of average inter-correlations among items, which determine the concepts." Although Bryman and Cramer (1990) suggested that, it is just fine when Cronbach's alpha is 0.8 or above 0.8, while Nunnally (1978) stated that it is still acceptable with the value of 0.6 .

Table 2.KMO and Bartlett's Test for Factors affecting the corporate customer satisfaction of Agribank in Ho Chi Minh City

\begin{tabular}{llr} 
Kaiser-Meyer-Olkin Measure of Sampling Adequacy. & $\frac{.793}{\text { Approx. Chi-Square }}$ & $\frac{11302.018}{253}$ \\
\cline { 3 - 4 } Bartlett's Test of Sphericity & Df & .000
\end{tabular}

Source: The authors' collecting data and SPSS

Table 2 showed that Kaiser-Meyer-Olkin Measure of Sampling Adequacy was statistically significant and high data reliability $(\mathrm{KMO}=0.793>0.6)$. This result was very good for data analysis. Table 2 showed that Cumulative percent was statistically significant and high data reliability was $75.875 \%$ (> $60 \%$ ). The result showed that Structure Matrix for the Factors affecting the corporate customer satisfaction of Agribank in Ho Chi Minh City had 5 Components. Component 1 was the service behavior, Component 2 was the tangible and the competitive price, Component 3 was the reliance, Component 4 was the convenience and Component 5 was The Agribank Image.

\section{Conclusions}

Structure Matrix for the Factors affecting the corporate customer satisfaction of Agribank in Ho Chi Minh City had 5 Components following:

Component 1 is service behavior (PCPV) include PCPV1, PCPV2, PCPV3, PCPV4 and PCPV5.

Component 2 is the tangible and the competitive price (SHH, TCTG) include SHH1, SHH2, SHH 3 andTCTG1, TCTG2, TCTG3.

Component 3 is the reliance (TXKH) includes TXKH1, TXKH2, TXKH 3 and TXKH4.

Component 4 is the convenience (STT) includes STT1, STT2, STT3 and STT4.

Component 5 is The Agribank Image (HADN) includes HADN1, HADN2, HADN3 and HADN4.

\section{References}

Band, W. A. (1991). Creating Value for Customers. New York: John Wiley.

Zeithaml, V. A., \&Mary Jo,B. (2001). Service Marketing. McGraw Hill Int.

Christopher Lovelock (2001). Services Marketing-People, Technology, Strategy. Pearson Education Asia.

Baron, S., \& Harris, K. (1995). Services Marketing. Palgrave Publishers Ltd.

Anderson, J. C., \& Narus, J. A. (1998).Business Marketing: Understand What the Customers Value. Harvard Business 
Review.

McDaniel, C.,\& Gates, R. (1996). Contemporary Marketing Research. South -Western College publishing.

Anderson, T.W. (1958). An Introduction to Multivariate Analysis. New York: John Wiley \& Sons.

Blaug, M. (2007). The Social Sciences: Economics. The New Encyclopædia Britannica.

Ackoff, R. L. (1961). The Design of Social Research. Chicago: University of Chicago Press.

Ackoff, R. L. (1962). Scientific Method. New York: John Wiley \& Sons.

Allen, T. H. (1978). New Methods in Social Science Research. New York: Praeger Publishers.

Anderson, T.W. (1958). An Introduction to Multivariate Analysis. New York: John Wiley \& Sons.

Bailey, K. D. (1978). Methods of Social Research. New York: John Wiley \& Sons.

Gronroos, C. (1984). Service Management and Marketing. Lexington Books, Lexington, MA.

Barzun, J., \& Graff, H. F. (1987). The Modern Researcher. New York: Harcourt, Brace.

Holbrook, M.B. (1994). The Nature of Customer Value, in: Rust, R. T.; Oliver, R. L. (eds.): Service Quality. New Directions in Theory and Practice, London Bell.

\section{(c) $)_{E Y}$}

This work is licensed under a Creative Commons Attribution 3.0 License. 